\title{
Examination of Body Composition, Flexibility, Balance, and Concentration Related to Dance Exercise
}

\author{
Gulsum Bastug ${ }^{1}$ \\ 'Mugla Sitki Kocman University, Faculty of Sports Sciences, Turkey \\ Email: gbastug@mu.edu.tr.Tel:002522111951
}

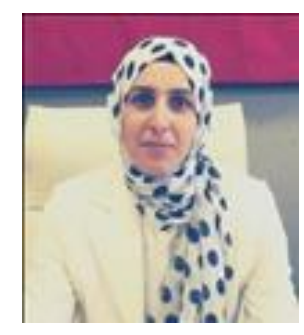

\begin{abstract}
In this study was to examine the body composition, flexibility, balance and concentration characteristics of dance exercise. Total of 268 university students whose average age was 20.59 \pm 1.59 years were included. Height measurements, body weight measurements, flexibility measurements, balance test, concentration test of the students who had dance courses (the experimental group) and those who did not have dance courses (the control group) were provided twice, at the beginning of and at the end of the study as pre-test and post-test. Frequency analyses, descriptive statistics, and paired t-test were used. There were significant differences between pre-test and post-test scores of body weight, BMI, flexibility, balance, concentration among the students doing dance exercises (the experimental group). There were no significant differences between pre-test and post-test scores of body weight, BMI, concentration among the students not doing dance exercises (the control group) but there were significant differences in flexibility and balance scores.
\end{abstract}

Keywords: Dance, Body composition, Flexibility, Balance, Concentration.

Citation | Gulsum Bastug (2018). Examination of Body Composition, Flexibility, Balance, and Concentration Related to Dance Exercise. Asian Journal of Education and Training, 4(3): 210215.

History:

Received: 8 May 2018

Revised: 31 May 2018

Accepted: 4 June 2018

Published: 8 June 2018

Licensed: This work is licensed under a Creative Commons

Attribution 3.0 License (c)

Publisher: Asian Online Journal Publishing Group
Funding: This study received no specific financial support.

Competing Interests: The author declares that there are no conflicts of interests regarding the publication of this paper.

Transparency: The author confirms that the manuscript is an honest, accurate, and transparent account of the study was reported; that no vital Transparency: The aulal study as planned have been explained.

Ethical: This study follows all ethical practices during writing.

\section{Contents}

1. Introduction

2. Methods ...

3. Measurements

4. Results

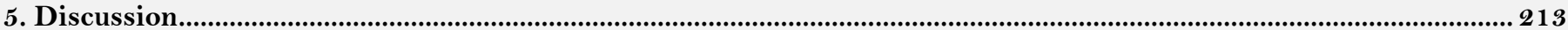

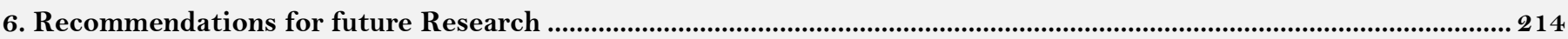

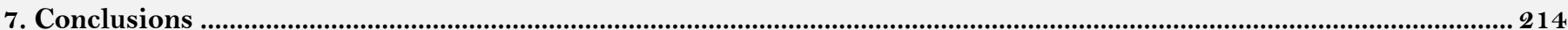

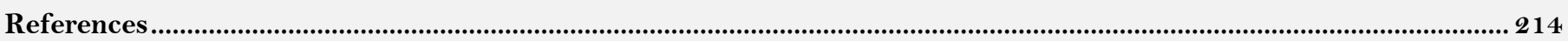




\section{Introduction}

Dance, being a special expression of human beings' motor behaviors (Hugel et al., 1999) is the art of reflecting inner world to outside, self-explanation and self-expression through movements (Cantekin, 2011). Dance, containing sports, science, and art in itself- is the expression of a feeling presented with a moving body through a physiological process (Esen, 2012). Thanks to dance, individuals have the opportunity to do more exercise (Lin, 2005). To support individuals emotionally, mentally, socially and physically and to understand the correlation between body and mind; the psycho-therapeutic dimension of movements should be used (Strassel et al., 2011). In addition to the use of dance as a tool that will help individuals explain themselves; benefits of dance in the human body as a sportive tool have been investigated by many studies (Adame et al., 1991; Hui et al., 2009). Dance, a multidimensional experience, involving emotional, physical, spiritual and social elements (Murciaa et al., 2010) can raise perceived levels of physical and mental well-being and social contact (Kierr, 2011) including among those diagnosed with depression and anxiety (Payne and Stott, 2010). Dance has such physical restrictions as muscle mass, joint structure, size, weight, flexibility and place (Stevens et al., 2000). Being the most aesthetic and rhythmic way of movement, dance is a technical and complex activity that contains exercises that strengthen the skeletonmuscle system as well as improves coordination by enabling the body to move freely in space/time. Thanks to images used, dance brings a new dimension to body awareness and improves imagination (Temel and Temel, 2016). In sport psychology, concentration or the ability to focus mental effort on the task at hand while ignoring distractions (Schmid and Peper, 1998) is defined as one's willing mental effort for the most important thing at that moment (Moran, 2004). Concentration in sports and exercise is composed of four parts: concentration on environmental clues (selective attention), attaining concentration focus during that moment, being aware of the situation and performance errors and changing concentration focus when necessary. Concentration is the ability to focus on relevant environmental clues. When the environment changes quickly, concentration focus should be quickly changed, too. Reflecting on the past or the future creates irrelevant clues; which leads to performance errors (Weinberg and Gould, 2015). In concentration, the person continues focusing until movement progress ends (Jackson et al., 2001). Flexibility is one of the basic motoric features and means performing movements in the widest scale and in the freest way (Dündar, 2012; Zorba and Saygin, 2013). Balance is a reflex realized by central nervous system and means fulfilling the tasks by the organism's movement system in static and dynamic harmony. The system that provides balance determines the place, position and direction of the body in space and decides whether or not body should be moving or standing firm (Horak and Macpherson, 2011). Balance is the ability to keep and to maintain the center of gravity within balance points (Deliagina et al., 2007). Thanks to dance; people can have a fit and aesthetic posture and attain balance, personal discipline, concentration, flexibility, endurance, speed and strength (Gökce, 2006). The essential physical qualifications for the dance are strength, flexibility, special endurance, balance, and body coordination (Hugel et al., 1999). Dancing could be seen as a medium for increasing leisure-time physical and social activity. A great body of literature reveals the importance of engaging in regular physical exercise for the prevention of several chronic diseases as well as for improving psychological wellbeing and overall quality of life (Warburton et al., 2006; Haskell et al., 2007). Adılogulları (2014) found that dance training reduces social physique anxiety. Because dancing provides individuals opportunity to share emotions, express themselves without any word, socialize, people may find the chance to move away from anxiety and stress of everyday life while dancing.

Dance is considered as a sport due to its movement-related skills and motor skills and as art due to visual and aesthetic aspects, is a practical activity that combines different disciplines. Today, positive physiological and psychological effects of dancing upon the human body and its contributions to motor growth have been investigated through scientific methods. Dance is thought to be important because unlike sportive activities, freedom of movement is offered by dancing to those who move away from physical activities and perform passive activities due to the effects of advanced technology and because their physical and psychological well-being is protected. In light of that background, the current study aimed at assessing body composition, flexibility, balance and concentration values among dancing individuals.

\section{Methods}

Participants and Procedures A total of 268 university students whose average age is $20.59 \pm 1.59$ years were recruited for the study (175 male students vs. 93 female students). In the study, university students received 3hour Latin dance courses (salsa, bachata) once a week for 12 weeks. The university students in the control group did not receive any dance courses. Height measurements, body weight measurements, flexibility measurements, balance test, concentration test of the students who had dance courses (the experimental group) and those who did not have dance courses (the control group) were provided twice at the beginning of and at the end of the study as pre-test and post-test. In order to determine concentration characteristics of the subjects, "Letter Cancellation Task" developed by Kumar and Telles (2009) was employed. Dances based on our research are Salsa, Zumba, Modern Dance. The most common dance of Latin American dances is Salsa. Salsa, a freestyle dance, is a type of dance that is improvised without adhering to routine movements (Craine and Mackrell, 2000). Zumba is a dance which combines Aerobic with music, figures of Oriental and Latin (merengue, salsa, bachata, reggaeton) dances (Micallef, 2014). Modern dance does not have specific special terms because it is shaped according to the personal creativity, the characteristics of the dancer and the creator's desire. In general, knowing dance terms is sufficient for modern dance (Cantekin, 2011). The experimental group was applied 30-70 min dance exercises (Salsa, Zumba, Modern Dance) for one day in a week throughout 14 weeks.

\section{Measurements}

Body weight and height: The weight was measured by an electronic balance with $0.1 \mathrm{~kg}$ sensitivity while the height was measured via digital height meter device with $0.01 \mathrm{~cm}$ sensitivity. Body composition: To determine body composition, body mass index (BMI) was calculated via weight/height2 (kg/m2) formula (WHO, 2012). Balance (Flamingo Balance Test-FDT): In order to explore the static balance of the participants, Flamingo 
Balance Test was used. The reliability coefficient of static balance was 0.87 (Johnson et al., 1987). According to the test, the study group stood on a stabilometry platform of $50 \mathrm{~cm}$ in length, $4 \mathrm{~cm}$. in height and $3 \mathrm{~cm}$. in width with the dominant/preferred foot and tried to achieve their balance. Other free leg was bent backward from knee, pulled up to hips and gripped with the hand on the same side and time started when the participants achieved his/her balance on one foot and tried to keep his/her balance for one minute. When the balance was lost (giving up gripping the foot, falling off the platform, touching any part of the body, etc.), time was stopped. When the participant achieved his/her balance on the platform again, time was resumed. The test continued for one minute. When time was up, the number of the balance lost was counted, and the number was written down as participants' balance score at the end of the test. Flexibility: Sit-reach test measures first knee hamstrings and second flexibility of lower back, hip, and calves. Specifically, it measures biceps, femur, semi tendons, semi membranes, erector spinae, gluteus maximus, medius and gastrocnemius muscles, tendons. Sit-reach test flexibility box was of $35 \mathrm{~cm}$ length, $45 \mathrm{~cm}$ width, $32 \mathrm{~cm}$ height and upper part of the box was $55 \mathrm{~cm}$ length, $45 \mathrm{~cm}$ widths. The upper part protruded $15 \mathrm{~cm}$ outward and was marked between 0 and $50 \mathrm{~cm}$ on the top. The participant placed the bottom of the foot against the side of the box without bending knees, stretched hands as far as possible, flexed his/body without bending knees and pushed the $30 \mathrm{~cm}$ ruler on the box as far as possible and stopped for a few seconds at the furthest point on the box. The test was twice repeated, and the best result was recorded as the flexibility result of the test (Zorba and Saygin, 2013).

Concentration: Letter cancellation task as used by Kumar and Telles (2009) was used to measure the level of concentration in participants. The task consisted of a block of randomly placed letters in 14 columns and 22 rows with six assigned letters listed at the top of the page which participants were required to cancel within the block in 90 seconds. Scores of concentration on the Letter Cancellation Task were calculated by counting the number of correctly canceled letters within the grid. This score represented the speed and accuracy of the participants' completion, and therefore their concentration level (Kumar and Telles, 2009).

Data process and analysis Collected data were processed with SPSS 22.0 program. For the analyses of the data; frequency analyses, descriptive statistics, and the paired t-test was used.

\section{Results}

Average age, height, body weight, BMI, flexibility, balance and concentration values of the students who took dance courses (the experimental group) and those who did not (the control group) were shown in Table 1. It was found that the participants' average age was $20.59 \pm 1.59$ years, average height was $1.70 \pm 0.08 \mathrm{~cm}$., average body weight was $67.2 \pm 11.3$ in the pre-test and $67.5 \pm 11.2 \mathrm{~kg}$ in the post-test, average BMI was $23.1 \pm 2.9$ in the pretest and $23.2 \pm 2.9$ in the post-test, average flexibility was $22.09 \pm 11.5 \mathrm{~cm}$. in the pre-test and $24.4 \pm 10.4 \mathrm{~cm}$. in post-test, average balance score was $4.1 \pm 3.8$ in the pre-test, and $2.6 \pm 2.8$ in the post-test and average concentration score was $43.3 \pm 11.1$ in the pre-test and $48.6 \pm 12.3$ in the post-test.

Table-1. The participant students of the experimental and the control groups in terms of pre-test and post-test results

\begin{tabular}{|c|c|c|c|c|c|c|}
\hline Variables & Experimental - Control group & Min. & Max. & $M$ & SD & Median \\
\hline Age (years) & & 17 & 31 & 20.59 & 1.94 & 20 \\
\hline Height $(\mathrm{cm})$ & & 1.50 & 1.97 & 1.70 & 0.08 & 1.70 \\
\hline \multirow[t]{2}{*}{ Body weight (kg) } & Pre-test & 42 & 99 & 67.2 & 11.3 & 68 \\
\hline & Post-test & 42 & 99 & 67.5 & 11.2 & 68 \\
\hline \multirow[t]{2}{*}{ BMI $\left(\mathrm{kg} / \mathrm{cm}^{2}\right)$} & Pre-test & 16.8 & 31.1 & 23.1 & 2.9 & 22.8 \\
\hline & Post-test & 17.2 & 31.2 & 23.2 & 2.9 & 22.8 \\
\hline \multirow[t]{2}{*}{ Flexibility $(\mathrm{cm})$} & Pre-test & 4 & 58 & 22.09 & 11.5 & 19 \\
\hline & Post-test & 3 & 57 & 24.04 & 10.4 & 23 \\
\hline \multirow[t]{2}{*}{ Balance (number of fault) } & Pre-test & 0 & 26 & 4.1 & 3.8 & 3 \\
\hline & Post-test & 0 & 18 & 2.6 & 2.8 & 2 \\
\hline \multirow[t]{2}{*}{ Concentration } & Pre-test & 10 & 70 & 43.3 & 11.1 & 44 \\
\hline & Post-test & 14 & 75 & 48.6 & 12.3 & 49 \\
\hline
\end{tabular}

M: Mean; SD: Standard deviation; Min.: Minimum; Max.: Maximum

Table-2. Comparison of pre-test and post-test results related to body weight, BMI, flexibility, balance, and concentration among the students who did dance exercises (the experimental group) and those who did not (the control group)

\begin{tabular}{|c|c|c|c|c|c|c|c|}
\hline Variables & Groups & & $n$ & $M$ & SD & $t$ & $\mathrm{p}$ \\
\hline \multirow{4}{*}{ Body weight } & \multirow[t]{2}{*}{ Experimental group } & Pre-test & 129 & 68.46 & 11.41 & \multirow[b]{2}{*}{-2.68} & \multirow[b]{2}{*}{$0.01 * *$} \\
\hline & & Post-test & 129 & 68.82 & 11.21 & & \\
\hline & \multirow[t]{2}{*}{ Control group } & Pre-test & 139 & 66.11 & 11.11 & \multirow[b]{2}{*}{-1.26} & \multirow[b]{2}{*}{0.21} \\
\hline & & Post-test & 139 & 66.32 & 11.15 & & \\
\hline \multirow{4}{*}{$\mathrm{BMI}\left(\mathrm{kg} / \mathrm{cm}^{2}\right.$} & \multirow[t]{2}{*}{ Experimental group } & Pre-test & 129 & 23.3 & 2.75 & \multirow[b]{2}{*}{-2.90} & \multirow[b]{2}{*}{$0.004^{* *} *$} \\
\hline & & Post-test & 129 & 23.5 & 2.76 & & \\
\hline & \multirow[t]{2}{*}{ Control group } & Pre-test & 139 & 22.8 & 3.03 & \multirow[b]{2}{*}{-1.26} & \multirow[b]{2}{*}{0.21} \\
\hline & & Post-test & 139 & 22.9 & 3.06 & & \\
\hline \multirow{4}{*}{ Flexibility (cm) } & \multirow[t]{2}{*}{ Experimental group } & Pre-test & 129 & 25.07 & 12.23 & \multirow[b]{2}{*}{-2.25} & \multirow[b]{2}{*}{$0.03^{*}$} \\
\hline & & Post-test & 129 & 27.10 & 10.96 & & \\
\hline & \multirow[t]{2}{*}{ Control group } & Pre-test & 139 & 19.32 & 10.19 & \multirow[b]{2}{*}{-2.69} & \multirow[b]{2}{*}{$0.01 * *$} \\
\hline & & Post-test & 139 & 21.21 & 9.07 & & \\
\hline \multirow{4}{*}{ Balance (number of fault) } & \multirow[t]{2}{*}{ Experimental group } & Pre-test & 129 & 4.21 & 3.49 & \multirow[b]{2}{*}{9.94} & \multirow[b]{2}{*}{$0.000^{* * * *}$} \\
\hline & & Post-test & 129 & 1.67 & 0.16 & & \\
\hline & \multirow[t]{2}{*}{ Control group } & Pre-test & 139 & 4.12 & 4.13 & \multirow[b]{2}{*}{2.27} & \multirow[b]{2}{*}{$0.03^{*}$} \\
\hline & & Post-test & 139 & 3.47 & 3.36 & & \\
\hline \multirow{4}{*}{ Concentration } & \multirow[t]{2}{*}{ Experimental group } & Pre-test & 129 & 42.16 & 11.46 & \multirow[b]{2}{*}{11.63} & \multirow[b]{2}{*}{$0.000^{*} * *$} \\
\hline & & Post-test & 129 & 52.89 & 11.63 & & \\
\hline & \multirow[t]{2}{*}{ Control group } & Pre-test & 139 & 44.41 & 10.76 & \multirow[b]{2}{*}{-0.46} & \multirow[b]{2}{*}{0.65} \\
\hline & & t-test & 9 & .74 & .72 & & \\
\hline
\end{tabular}

*p $<0.05,{ }^{* *} \mathrm{p}<0.01,{ }^{* * *} \mathrm{p}<0.001$ 
As seen in Table 2, it was identified that there was a significant difference among the students who did dance exercises (the experimental group) regarding pre-test and post-test values concerning body weight, BMI, flexibility, balance, and concentration $(\mathrm{p}<0.05)$. Average body weight was $68.46 \pm 11.41 \mathrm{~kg}$ in the pre-test and $68.82 \pm 11.21 \mathrm{~kg}$ in the post-test, average BMI was $23.3 \pm 2.75$ in the pre-test and $23.5 \pm 2.76$ in the post-test, average flexibility was $25.07 \pm 12.23 \mathrm{~cm}$ in the pre-test and $27.10 \pm 10.96 \mathrm{~cm}$ in the post-test, average balance score was $4.21 \pm 3.49$ in the pre-test, and $1.67 \pm 1.82$ in the post-test and average concentration score was $42.16 \pm$ 11.46 in the pre-test and $52.89 \pm 11.63$ in the post-test. It was found that body weight and BMI pre-test and posttest values of the students who did dance exercises were similar while their flexibility, balance and concentration pre-test and post-test values improved.

As for the students who did not do dance exercises (the control group); no significant difference was seen regarding pre-test and post-test body concerning weight, BMI and concentration values ( $>0.05)$; however, their flexibility and balance scores differed considerably $(\mathrm{p}<0.05)$. It was identified that average body weight was 66.11 \pm 11.11 in the pre-test and $66.32 \pm 11.15$ in the post-test, average BMI was $22.8 \pm 3.03$ in the pre-test and $22.9 \pm 3.06$ in the post-test, average concentration score was $44.41 \pm 10.76$ in the pre-test and $44.74 \pm 11.72$ in the post-test. When the significant difference in flexibility and balance values of the students who did not do dance exercises was examined; it was seen that the average flexibility and average balance scores decreased with an average flexibility score being $19.32 \pm 10.19$ in the pre-test and $9.07 \pm 0.76$ in the post-test and average balance score being $4.12 \pm 4.13$ in the pre-test and $3.47 \pm 3.36$ in the post-test (Table 2 ).

\section{Discussion}

In the study of body composition, flexibility, balance, and concentration related to dance exercise; average age, height, body weight, BMI, flexibility, balance and concentration values of the participant students of the experimental and control groups were presented. It was noted that the participants' average age was (20.59 \pm $1.59)$ years, average height was $(1.70 \pm 0.08 \mathrm{~cm}$.), average body weight was $(67.2 \pm 11.3)$ in the pre-test and $(67.5$ $\pm 11.2)$ in the post-test, average BMI was $(23.1 \pm 2.9)$ in the pre-test and $(23.2 \pm 2.9)$. In the post-test, average flexibility was $(22.09 \pm 11.5) \mathrm{cm}$. in the pre-test and $(24.4 \pm 10.4) \mathrm{cm}$. in post-test, average balance score was $(4.1$ $\pm 3.8)$ in the pre-test and $(2.6 \pm 2.8)$ in the post-test and average concentration score was $(43.3 \pm 11.1)$ in the pretest and $(48.6 \pm 12.3)$ in the post-test (Table 1). Dance development can be multidimensional among individuals and brings about positive improvements when individuals dance as a sportive activity or physical activity. Numerous studies emphasize physiological and psychological benefits of dancing (Hackney and Earhart, 2010; Hanna, 2010; Huddy and Stevens, 2011; Zitomer and Reid, 2011). It was found that hopelessness levels of the university students who danced decreased (Bastug and Demir, 2010). Minton (2003) reported that students who received dancing classes had more abstract and creative thinking skills compared to those who did not receive dancing courses. Fonseca et al. (2014) observed that ballroom dancing brought perceptual benefits for those who practiced it. Krampe (2013) found that dance-based therapy was mildly or moderately effective in several components of balance and mobility. It was identified that motivation, self-confidence, body language, dancing related self-sufficiency and dance performances improved positively (Tokinan and Bilen, 2011). In a study on concentration, it was observed that concentration levels and feeling-states improved significantly over sessions of both yoga and aerobic exercise sessions equally. Aerobic exercise and yoga both produce positive changes in concentration, stress, energy, and well-being while only yoga produces improvements in mood and self-satisfaction (Dolde, 2011). Dancing, playing games, painting, and singing by the children support growth as well as play a key role in brain's learning skills and improve all of the senses (Bradley et al., 2013). It was identified that university students who participated in dancing activities had positive perceptions about social, physical anxiety levels and higher satisfaction with body image (Cepikkurt and Coşkun, 2010). Akandere et al. (2010) found that the problemsolving skills of the subjects participated in research differed at the beginning and the end of dance exercise.

It was detected that there was a significant difference between pre-test and post-test values of the students who did dancing exercises (the experimental group) and those who did not regarding body weight, BMI, flexibility, balance and concentration scores. The average values were as follows: pre-test body weight (68.46 \pm $11.41 \mathrm{~kg})$ and post-test body weight $(68.82 \pm 11.21 \mathrm{~kg})$, pre-test BMI $(23.3 \pm 2.75)$ and post-test BMI $(23.5 \pm$ $2.76)$, pre-test flexibility $(25.07 \pm 12.23)$ and post-test flexibility $(27.10 \pm 10.96)$, pre-test balance $(4.21 \pm 3.49)$ and post-test balance (1.67 \pm 1.82$)$, pre-test concentration (42.16 \pm 11.46$)$ and post-test concentration (52.89 \pm 11.63$)$. Among the students who did dancing exercises, body weight and BMI pre-test and post-test values were similar to each other, but their flexibility, balance and concentration pre-test and post-test values improved. As for the students who did not do dancing exercises (the control group); there was not a significant difference between pretest and post-test values in terms of body weight, BMI, and concentration. However, their flexibility and balance values were different. The average values were as follows: pre-test body weight (66.11 \pm 11.11$)$ and post-test body weight $(66.32 \pm 11.15)$, pre-test BMI $(22.8 \pm 3.03)$ and post-test BMI $(22.9 \pm 3.06)$, pre-test concentration $(44.41$ $\pm 10.76)$ and post-test concentration $(44.74 \pm 11.72)$. When the significance in flexibility and balance values of the students who did not do dancing exercises was examined, it was observed that there were decreases from $(19.32 \pm 10.19)$ (pre-test) to $(9.07 \pm 0.76)$ (post-test) in flexibility and from $(4.12 \pm 4.13)$ (pre-test) to $(3.47 \pm 3.36)$ (post-test) in balance (Table 2). In the study of Gardner et al. (2009) it was pointed out that dance encourages physical activity and contributes to wish to live healthily to a great extent. Results obtained with the sit-reach test in the stretching exercise showed an increase in flexibility values (Nelson et al., 2005). The results of present investigation demonstrated that international level dance sport dancers of different styles have relatively high aerobic capacity values compared to the other dance styles (ballet, modern dance, flamenco and folk dance) and the aerobic capacity values of the three dance styles are rather similar. No significant relationship was found in the current study between the international ranking and aerobic capacity values (Liiv et al., 2014). In a study of dance and imagery, it has been determined that imagination develops the technical skill (Muir and Munroe-Chandler, 2017). In dance courses, participants did turning, crawling, rolling, swinging, tumbling, stretching and jumping as exercises. In the study, it was seen that students who joined dance exercises demonstrated a higher level of concentration (Spielmann, 2013). It was remarked that dance, based on movements, increased individuals' quality 
of life and physical activities produced positive effects upon learning skills (Demirel and Temel, 2016). Bastug et al. (2016) found that an apparent difference was found between body weight and BMI pre-test and post-test values of women who were applied mixed exercise program (Cross Fit, Pilates, Zumba). A decrease was observed in both body weight and average means of BMI of women. A significant difference was not found between body weight, BMI and body areas satisfaction pre-test and post-test values of women in control group. It was concluded that Cross Fit, Pilates, Zumba exercises affected body weight, BMI, and content with body areas positively. Dancing has potentially positive benefits on well-being in several aspects. In particular, beneficial effects were found related to the emotional dimension, as well as physical, social and spiritual dimensions. Also, the positive benefits were also linked to self-esteem and coping strategies (Murciaa et al., 2010). Babayigit et al. (2014) indicate that weight loss program with a step dance and aerobic dance are as useful tools as the other sports which enable to decrease body fat percentage, in improving weight for university students. The Zumba fitness program was designed to improve the cardiovascular risk factors of the Zumba fitness program for overweight non-exercise women in the study of health benefits (Domene et al., 2016).

\section{Recommendations for future Research}

It is expected that the results of these studies will contribute to the work done in the field of dance. Dance instructors and students are recommended to perform flexibility, balance, concentration studies. It is also suggested to examine the attention and mental endurance characteristics of dance exercises.

\section{Conclusions}

In conclusion, the body composition, flexibility, balance and concentration characteristics of dance exercise were examined. An apparent difference was found between pre-test and post-test values among students who did dancing exercises (the experimental group) in terms of body weight, BMI, flexibility, balance, and concentration. Body weight and BMI pre-test-post-test average values were similar to each other among the students who did dancing exercises, and their flexibility, balance, and concentration pre-test-post-test average values improved positively. As for the students who did not dancing exercises (the control group), no significant difference was found between pre-test and post-test values regarding body weight, BMI and concentration values but their flexibility and balance values differed significantly. When the apparent difference of flexibility and balance values among students who did not do dancing exercises was investigated, it was remarkable that there was a decrease between pre-test and post-test average values. Balance and flexibility values of the students who did not do dancing exercises reduced; which indicated that balance and flexibility negatively changed. As proved by the scientific findings in the current article, there was a direct and important difference between dancing exercises and body composition, flexibility, balance, concentration. We can suggest that dance makes positive contributions to people's physical, motoric and psychological growth.

\section{References}

Adame, D.D., S.A. Radell, T.C. Johnson and S.P. Cole, 1991. Physical fitness, body image, and locus of control in college women dancers and no dancers. Perceptual and Motor Skills, 72(1): 91-95. View at Google Scholar | View at Publisher

Adılogulları, I., 2014. The examining the effects of 12-week Latin dance exercise on social physique anxiety: The effects of 12-week Latin dance. Anthropologist, 18(2): 42 1-425. View at Google Scholar | View at Publisher

Akandere, M., G. Bastug, H. Demir and Ö. Taşgin, 2010. Examining problem-solving skills of the students practicing dance for 12 weeks in terms of gender variable. Ovidius University Annals, Series Physical Education and Sport / Science, Movement and Health, 10(2): 635-638. View at Google Scholar

Babayigit, İ.G., Ö. Saygın, S. Yildirim and H.I. Ceylan, 2014. Aerobic dance or step dance: Which exercise can increase balance, flexibility and muscle strength of university students? SSTB International Refereed Academic Journal of Sports, Health \& Medical Sciences, 13(4): 143-163. View at Google Scholar

Bastug, G. and B. Demir, 2010. Examination of the hopelessness levels of university students who are studying dance for twelve weeks according to gender variable, 3. Women as an International Science category; Women's Symposium on Literature, Language, Culture and Art studies, Selcuk University, Dilek Sabanci State Conservatory, 28-30 April, Turkey.

Bastug, G., R. Özcan, D. Gültekin and Ö. Günay, 2016. The effects of cross fit, pilates and zumba exercises on body composition and body Image of women. International Journal of Sports, Exercise and Training Science, 2(1): 146-153.

Bradley, K., J. Bonbright and S. Dooling, 2013. Evidence: A report on the impact of dance in the K-12 setting. National Dance Education Organization. Retrieved from www.arts.gov/sites/default/files/ResearchArt-Works-NDEO.pdf.

Cantekin, D., 2011 . Examination of movement related terms used in dance. Master thesis. Sakarya (Turkey): Sakarya University, Institute of Social Sciences.

Cepikkurt, F. and F. Coşkun, 2010. Social physique anxiety and body image satisfaction levels of collegian dancers. Pamukkale Journal of Sport Sciences, 1(2): 17-24. View at Google Scholar

Craine, D. and J. Mackrell, 2000. The Oxford dictionary of dance. New York: Oxford University Press Inc. pp: 416-466.

Deliagina, T.G., P.V. Zelenin, I.N. Beloozerova and G.N. Orlovsky, 2007. Nervous mechanisms controlling body posture. Physiology \& Behavior, 92(1-2): 148-154. View at Google Scholar $\mid$ View at Publisher

Demirel, T.S. and T. Temel, 2016. The contribution of dance education to physical-mental development, movement ability and learning processes. Fine Arts (NWSAFA), $11(4)$ : 171-180. View at Publisher

Dolde, E.J., 2011. The effects of yoga and aerobic exercise on concentration and feeling-states. Roger Williams University, Honors Theses, 3.

Domene, P.A., H.J. Moir, E. Pummell, A. Knox and C. Easton, 2016. The health-enhancing efficacy of Zumba ${ }^{\circledR}$ fitness: An 8-week randomized controlled study. Journal of Sports Sciences, 34(15): 1396-1404. View at Google Scholar | View at Publisher

Dündar, U., 2012. Training theory. Ankara, Turkey: Nobel Publication Distribution.

Esen, A., 2012. The effect of dance training on joint position sensing levels. Master Thesis. İzmir (Turkey): Ege University, Health Sciences Institute.

Fonseca, C.C., B.E. Thurm, R.L. Vecchi and E.F. Gama, 2014. Ballroom dance and body size perception. Perceptual and Motor Skills, 119(2): 495-503. View at Google Scholar | View at Publisher

Gardner, S.M., P. Komesaroff and R. Fensham, 2009. Dancing beyond exercise: Young people's experiences in dance classes. Journal of Youth Studies, 11(6): 701-709.

Gökce, E., 2006. The effect of 20-week special stretching exercise program on flexibility and dance performance in dancers who are trained in professional dance. Master Thesis, Istanbul (Turkey): Mimar Sinan University, Social Sciences Institute.

Hackney, M.E. and G.M. Earhart, 2010. Effects of dance on balance and gait in severe Parkinson disease: A case study. Disability and Rehabilitation, 32(8): 679-684. View at Google Scholar | View at Publisher

Hanna, L.J., 2010. Dance and sexuality: Many moves. Journal of Sex Research, 47(2-3): 212-241. View at Google Scholar $\mid$ View at Publisher 
Haskell, W.L., I.M. Lee, R.R. Pate, K.E. Powell, S.N. Blair, B.A. Franklin and A. Bauman, 2007. Physical activity and public health: Updated recommendation for adults from the American college of sports medicine and the American heart association. Medicine and Science in Sports and Exercise, 39(8): 1423-1434. View at Google Scholar | View at Publisher

Horak, F.B. and J.M. Macpherson, 2011. Postural orientation and balance. Comprehensive Physiology: 255-292. Retrieved from http://www.comprehensivephysiology.com/WileyCDA/CompPhysArticle/refId-cp 120107.html.

Huddy, A. and K. Stevens, 2011. The teaching artist: A model for university dance teacher training. Research in Dance Education, 12(2): 157-171. View at Google Scholar | View at Publisher

Hugel, F., M. Cadopi and P. Perrin, 1999. Postural control of ballet dancers: A specific use of visual input for artistic purposes. International Journal Sports Medicine, 20(2): 86-92. View at Google Scholar | View at Publisher

Hui, E., B.T. Chui and J. Woo, 2009. Effects of dance on physical and psychological well-being in older persons. Archives of Gerontology and Geriatrics, 49(1): 45-50. View at Google Scholar $\mid$ View at Publisher

Jackson, S.A., P.R. Thomas, H.W. Marsh and C.J. Smethurst, 2001. Relationships between flow, self-concept, psychological skills, and performance. Journal of Applied Sport Psychology, 13(2): 129-153. View at Google Scholar | View at Publisher

Johnson, R.E., D.R. Kirkendall and J.J. Gruber, 1987. Measurement and evaluation for PE. USA: Human Kinetics Publishers.

Kierr, S., 2011. Is dance/movement therapy relevant to the process of achieving a healthy sexuality? American Journal of Dance Therapy, $33(1): 42-56$.

Krampe, J., 2013. Exploring the effects of dance-based therapy on balance and mobility in older adults. Western Journal of Nursing Research, 35(1): 39-56. View at Google Scholar | View at Publisher

Kumar, S. and S. Telles, 2009. Meditative states based on yoga texts and their effects on performance of a letter-cancellation task. Perceptual and Motor Skills, 109(3): 679-689. View at Google Scholar | View at Publisher

Liiv, H., T. Jürimäe, J. Mäestu, P. Purge, A. Hannus and J. Jürimäe, 2014. Physiological characteristics of elite dancers of different dance styles. European Journal of Sport Science, 14(sup 1): S429-S436. View at Google Scholar $\mid$ View at Publisher

Lin, C.M., 2005. Perception of dance instructors regarding general dance education curricula in Taiwan. USA: The University of South Dakota.

Micallef, M., 2014. The effectiveness of an 8-week Zumba programme for weight reduction in a group of maltese overweight and obese women. Sport Sciences for Health, 10(3): 211-217. View at Google Scholar | View at Publisher

Minton, S., 2003. Assessment of high school students' creative thinking skills, a comparison of dance and nondance classes. Research in Dance Education, 4(1): 31-49. View at Google Scholar $\mid$ View at Publisher

Moran, A., 2004. Sport and exercise psychology: A critical introduction. London: Routledge. Muir, I.L. and K.J. Munroe-Chandler, 2017. Imagery exercises for young highland dancers. Journal of Dance Education, 17(1): 21-26. View at
Google Scholar $\mid$ View at Publisher

Murciaa, C.Q., G. Kreutzb, S. Cliftc and S. Bongarda, 2010. Shall we dance? An exploration of the perceived benefits of dancing on wellbeing. Arts and Health, 2(2): 149-163. View at Google Scholar $\mid$ View at Publisher

Nelson, A.G., J. Kokkonen and D.A. Arnall, 2005. Acute muscle stretching inhibits muscle strength endurance performance. Journal of Strength and Conditioning Research, 19(2): 338-343. View at Google Scholar | View at Publisher

Payne, H. and D. Stott, 2010. Change in the moving body mind: Quantitative results from a pilot study on the use of the Body mind approach (BMA) to psychotherapeutic group work with patients with medically unexplained symptoms (MUSS). Counseling and Psychotherapy Research, 10(4): 295-306. View at Google Scholar $\mid$ View at Publisher

Schmid, A. and E. Peper, 1998. Strategies for training concentration, In J.M. Williams (Ed.), Applied sport psychology: Personal growth to peak performance (3rd Edn.,). Mountain View, CA: Mayfield. pp: 316-28.

Spielmann, C., 2013. The effects of movement based learning on student achievement in the school classroom. Retrieved from https://www.trikke.com/wp-content/uploads/2013/07/Physical-Movement-Learning-Study.pdf.

Stevens, K., S. Mckechnie, S. Malloch and A. Petocz, 2000. Choreographic cognition: Composing time and space. Australia: ICMPC.

Strassel, J.K., D.C. Cherkin, L. Steuten, K.J. Sherman and H.J.M. Vrijhoef, 2011. A systematic review of the evidence for the effectiveness of dance therapy. Alternative Therapies, 17(3): 50-59. View at Google Scholar

Temel, S.D. and T. Temel, 2016. The contribution of dance education to physical-mental development, movement ability and learning processes. Fine Arts (NWSAFA), 1 1(4): 171-180. View at Google Scholar | View at Publisher

Tokinan, B.Ö. and S. Bilen, 2011. The effects of creative dancing activities on motivation, self-esteem, self-efficacy and dancing performance. Hacettepe University Journal of Education, 40: 363-374. View at Google Scholar

Warburton, D.E., C.W. Nicol and S. Bredin, 2006. Health benefits of physical activity: The evidence. Canadian Medical Associa tion Journal, 174(6): 801-809. View at Google Scholar | View at Publisher

Weinberg, R.S. and D. Gould, 2015. Foundations of sport and exercise psychology. 6th Edn., Champaign, IL: Human Kinetics.

WHO, 2012. Obesity and overweight. Retrieved from http://www.who.int/mediacentre/factsheets/fs311/en/index.html [Accessed 28 February 2016].

Zitomer, M.R. and G. Reid, 2011. To be or not to be-able to dance: Integrated dance and children's perceptions of dance ability and disability. Research in Dance Education, 12(2): 137-156. View at Google Scholar $\mid$ View at Publisher

Zorba, E. and Ö. Saygin, 2013. Physical activity and physical fitness. Firat printing. 3rd Edn. pp: 138-151. 